\title{
Cellular and Molecular Abnormalities of a Macronodular Adrenal Hyperplasia Causing Beta-Blocker-Sensitive Cushing's Syndrome
}

\section{artigo original}

\author{
TÂNIA L. MAZZUCO \\ MICHAËL THOMAS \\ MONIQUE MARTINIE \\ NADIA CHERRADI \\ NATHALIE STURM \\ JEAN-JACQUES FEIGE \\ Olivier Chabre
}

Unité INSERM 878, Institut de Recherches en Technologies et Sciences pour le Vivant - iRTSV, CEA-Grenoble (TLM, MT, NC, J-JF \& OC); Service d'Endocrinologie,

Département de Diabétologie

Urologie Néphrologie

Endocrinologie - DUNE (TLM,

MM \& OC) and Laboratoire de Pathologie Cellulaire,

Département d'Anatomie et

de Cytologie Pathologiques

(NS), CHU-Grenoble, France.

Recebido em 11/12/06 Aceito em 31/07/07

\section{ABSTRACT}

Cushing's syndrome due to ACTH-independent macronodular adrenal hyperplasia (AIMAH) can be associated with abnormal responses of aberrantly expressed adrenocortical receptors. This study aimed to characterize in vitro the pathophysiology of hypercortisolism in a $\beta$-blocker-sensitive Cushing's syndrome due to AIMAH. Cortisol secretion profile under aberrant receptors stimulation revealed hyperresponsiveness to salbutamol ( $\beta 2$-adrenoceptor agonist), cisapride (5-HT4 receptor agonist), and vasopressin in AIMAH cultured cells, but not in normal adrenocortical cells. By RT-PCR, AIMAH tissues revealed $\beta 2$-adrenoceptor overexpression rather than ectopical expression. MC2R expression was similar in both AIMAH and normal adrenocortical tissues. Curiously, cortisol levels of AIMAH cells under basal condition were 15-fold higher than those of control cells and were not responsive to ACTH. Analysis of culture medium from AIMAH cells could detect the presence of ACTH, which was immunohistochemically confirmed. Finally, the present study of AIMAH cells has identified: a) cortisol hyperresponsiveness to catecholamines, 5-HT4 and vasopressin in vitro, in agreement with clinical screening tests; b) abnormal expression of $\beta 2$-adrenoceptors in some areas of the hyperplastic adrenal tissue; c) autocrine loop of ACTH production. Altogether, the demonstration of aberrant responses to hormonal receptors and autocrine hormone production in the same tissue supports the assumption of multiple molecular alterations in adrenal macronodular hyperplasia. (Arq Bras Endocrinol Metab 2007;51/9:1452-1462)

Keywords: Adrenal glands/ (pathol); Hyperplasia; Hormone receptors; Cell surface; Adrenocorticotropic hormone; Adrenocortical hyperfunction; Cushing syndrome

\section{RESUMO}

\begin{abstract}
Alterações Celulares e Moleculares de uma Hiperplasia Adrenal Macronodular Responsável por Síndrome de Cushing Responsiva a Beta-Bloqueadores. A síndrome de Cushing secundária à hiperplasia adrenal macronodular independente de ACTH (AIMAH) pode estar associada com respostas anômalas a estímulos sobre receptores hormonais expressos de maneira aberrante no córtex adrenal. O objetivo deste trabalho foi caracterizar a fisiopatologia do hipercortisolismo in vitro na síndrome de Cushing responsiva a $\beta$-bloqueadores decorrente de AIMAH. Em cultura de células, a secreção de cortisol apresentou resposta aumentada ao salbutamol (agonista $\beta 2$-adrenérgico), à cisaprida (agonista de receptor 5 -HT4) e à vasopressina, na AIMAH mas não no córtex adrenal normal. $O$ estudo de receptores aberrantes por RTPCR demonstrou que o gene do receptor $\beta 2$-adrenérgico estava superexpresso (e não expresso ectopicamente) nos fragmentos da AIMAH quando comparado ao tecido normal. A expressão de MC2R foi semelhante em ambos. Curiosamente, o nível basal de secreção de cortisol pelas células da AIMAH foi 15 vezes superior às células normais, não havendo resposta das células AIMAH ao estímulo com ACTH. A análise do meio de cultura das células AIMAH revelou a presença de ACTH, que foi confirmada por estudo imuno-histoquímico. Em suma, este estudo demonstrou: a) aumento dos níveis de cortisol in vitro em resposta a catecolaminas, 5-HT4 e vasopressina, correspondendo aos resultados dos testes clínicos para pesquisa de receptores aberrantes; b) expressão anormal de receptores $\beta 2$-adrenérgicos em algumas áreas de hiperplasia; c) produção autócrina de ACTH. Estes resultados envolvendo ativação de receptores aberrantes e estímulo hormonal autócrino no mesmo tecido favorecem a hipótese da existência de alterações moleculares múltiplas na hiperplasia adrenal macronodular. (Arq Bras Endocrinol Metab 2007;51/9:1452-1462)
\end{abstract}

Descritores: Glândulas supra-renais/ (patol); Hiperplasia; Receptores hormonais da superfície celular; Hormônio adrenocorticotrópico; Hiperfunção adrenocortical; Síndrome de Cushing 
S EVERAL OBSERVATIONS INDICATE that Cushing's syndrome caused by corticotrophin (ACTH)-independent tumors or macronodular adrenal hyperplasia (AIMAH) can be accounted for aberrant responsiveness of the tissue to various hormones or neurotransmitters, including gastric inhibitory polypeptide (GIP), epinephrine, vasopressin (AVP) or serotonin (5-HT) (1). Catecholamine-dependent Cushing's syndrome is a rare condition that has been clinically reported in six cases at present (2-7).

Previous in vitro reports have provided some evidence for abnormal responses to $\beta$-adrenergic stimuli on adrenocortical tumors. These adrenal $\beta$-adrenergic responses were first studied in the rat adrenocortical carcinoma 494 cells in which abnormal activation of adenylate cyclase (AC) by catecholamines (8) and the presence of isoproterenol binding sites (absent in membranes of normal adrenal tissue) were characterized (9). In human adrenocortical tissues, activation of AC by norepinephrine and/or epinephrine was observed in adenomas (10), in adrenocortical carcinomas (11), and in one case of AIMAH (2) but not in normal tissues (11). The presence of $\beta$-adrenergic binding sites was also shown in that same case of AIMAH (2), in cortisol-producing adenomas (12) and in adrenocortical carcinomas (11). Prior to these in vitro studies, a catecholamine-dependent Cushing's syndrome was clinically characterized in only two cases $(2,6)$. These include a case with a simultaneous expression of several aberrant hormone receptors, a mild cortisol response to isoproterenol in vivo and an absence of $\beta$-adrenoceptor mRNA detection by RT-PCR (6).

We have previously described a clinical case of bilateral AIMAH with hypercortisolism sensitive to $\beta$ blockade (4), characterizing a catecholamine-dependent Cushing's syndrome that was well controlled by $\beta$ adrenergic antagonist treatment. Clinical screening tests performed to search for cortisol elevation in response to several ligands revealed other potential abnormally expressed receptors in adrenal cortex, such as $5 \mathrm{HT}_{4}$ and AVP receptors. Later on, the occurrence of pharmacological therapy intolerance led to the surgical excision of the larger adrenal gland of this patient. Hyperplastic tissue could thus be obtained for in vitro assays that allowed us to study the abnormal response to $\beta$-adrenoceptor stimulation and to determine which type of $\beta$ receptor is implicated in this response.

Here we report the cortisol responses of AIMAH cells to diverse in vitro pharmacological tests in order to compare with previous in vivo responses obtained in clinical screening tests searching for aberrant adrenal receptors expression. Our findings indi- cate that the abnormal clinical responsiveness to catecholamines was a result of abnormal expression of $\beta 2$ adrenoceptors in the hyperplastic tissue. Comparison with normal tissue suggested $\beta 2$-adrenoceptor overexpression rather than ectopic expression as mentioned in the literature. In vitro assays showed cellular hyperresponsiveness to 5 -HT and AVP, confirming the results of the clinical assays. Finally, basal overproduction of cortisol by AIMAH cells led us to identify an autocrine loop of ACTH production.

\section{MATERIALS AND METHODS}

\section{Clinical investigation protocol}

A 64 yr-old Caucasian woman presenting ACTH-independent hypercortisolism due to AIMAH was investigated for abnormal expression of adrenal receptors (4). After her informed consent, plasma levels of steroids in response to various stimuli were investigated using the protocol described by Lacroix et al. (13). The protocol consisted of monitoring plasma cortisol, aldosterone, and ACTH concentrations at 30-60 min intervals for $2-3 \mathrm{~h}$ during the tests as follow: supine-to-upright posture test, standard mixed meal, combined i.v. administration of $200 \mu \mathrm{g}$ TRH and 100 $\mu \mathrm{g}$ LHRH (Stimu-TSH and Stimu-LH, Ferring, Gentilly, France), combined administration of $1 \mathrm{mg}$ glucagon (GlucaGen, Novo Nordisk, Puteaux, France) i.v. and cisapride (Prepulsid, Janssen-Cilag, Issy-les-Moulineaux, France) orally, $1 \mathrm{mg}$ terlipressin (Glypressine, Ferring, Gentilly, France) i.v, $10 \mu \mathrm{g}$ desmopressin (Minirin, Ferring, Gentilly, France) i.v., 6 IU regular insulin (Actrapid, Novo Nordisk, Bagsvaerd, Denmark) i.v, or $0.25 \mathrm{mg}$ tetracosactide (Synacthène, Novartis Pharma, Rueil-Malmaison, France) i.v. as reference test. Cortisol response to the hypoglycemia (insulin test) was investigated after normalization of blood glucose levels of this diabetic patient.

\section{Tissue collection and cell culture}

After surgery, the hyperplastic left adrenal gland (figure 1) was collected and different tissue fragments were either fixed in formalin for further paraffin inclusion and hematoxylineosin staining, or immediately transported to the laboratory in ice-cold culture medium for primary culture. Fresh tissue were dissected and separated from fat and tissue adjacent to the central vein, in order to eliminate the adrenal medulla. Adrenocortical tissue fragments (12 $\mathrm{g}$ of diffuse adrenal hyperplasia and two small nodules of 1 and $0.4 \mathrm{~g}$ ) were minced with scissors and washed three times in Ham's F-12DMEM (1:1) medium containing $10 \mathrm{mmol} / \mathrm{L}$ Hepes, 14 $\mathrm{mmol} / \mathrm{L} \mathrm{NaHCO} 3$, and antibiotics $(20 \mathrm{U} / \mathrm{mL}$ penicillin, $50 \mu \mathrm{g} / \mathrm{mL}$ streptomycin, and $20 \mathrm{U} / \mathrm{mL}$ nystatin) (Life Technologies, Cergy Pontoise, France). Cells were enzymatically dispersed in $50 \mathrm{~mL}$ of culture medium containing adding $3 \mathrm{mg} / \mathrm{mL}$ collagenase A (Boehringer Mannheim, 

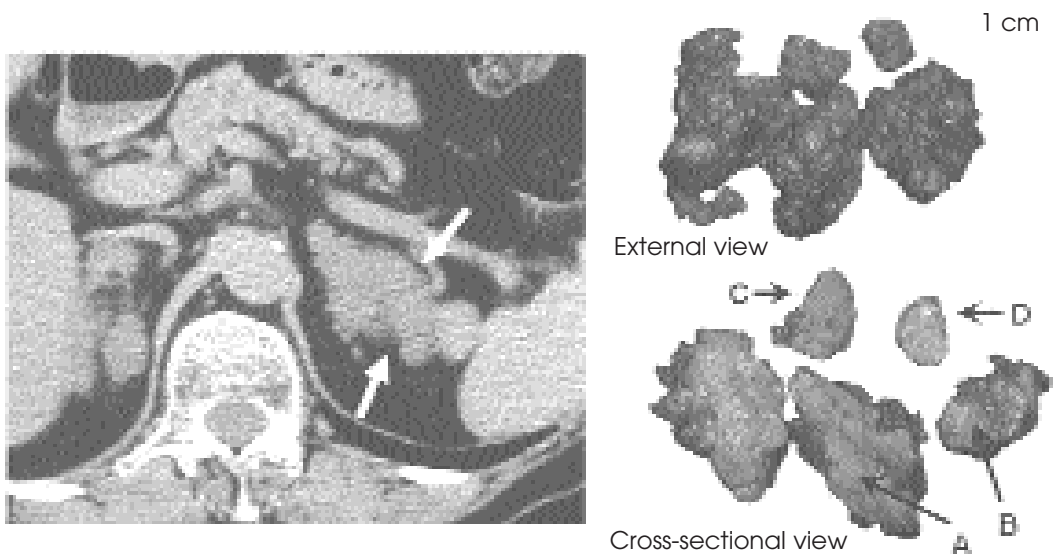

Figure 1. Radiologic and macroscopic morphology of the adrenal hyperplasia. Plan abdominal computed tomographic scan shows bilateral adrenal enlargement (left gland is indicated by the white arrow). The entire surgical piece of left adrenal was composed of a large polylobulated mass with two satellite nodules smaller than $2 \mathrm{~cm}$. Four tissue fragments (A, B, C, and D) were collected for RNA extraction.

Indianapolis, IN) and $0.1 \mathrm{mg} / \mathrm{mL}$ deoxyribonuclease (Sigma, Saint Quentin Fallavier, France), for $30 \mathrm{~min}$ at $37^{\circ} \mathrm{C}$ under stirring. The suspension was then filtered on sterile nylon sieve (100 $\mu \mathrm{m}$ mesh), completed with culture medium up to $50 \mathrm{~mL}$ and centrifuged for $10 \mathrm{~min}$ at $400 \mathrm{x} \mathrm{g}$. Cells prepared from different fragments were pooled because the number of cells from small nodules was insufficient to perform individualized culture experiments. Adrenocortical cells were then seeded in Petri dishes at a density of $10^{6}$ cells/dish with supplemented Ham's F-12-DMEM (1:1) medium containing 10\% horse serum (Eurobio, Les Ulis, France) and $2.5 \%$ fetal calf serum (FCS) (Life Technologies) with antibiotics, $0.5 \%$ insulin-transferrin-sodium selenite medium supplement (ITS) (Sigma), and incubated at $37^{\circ} \mathrm{C}$ in a $5 \%$ CO2-95\% air atmosphere. The culture medium was renewed 24 h later. Normal adrenal cells were prepared from a normal gland collected from a brain-dead patient undergoing nephrectomy for renal transplantation, following the same procedure as described above. All studies were performed in accordance to the guidelines of the institutional Human Research Ethics Committee.

\section{In vitro cortisol production}

Confluent cultured cells were trypsinized and plated in supplemented medium in multiwell dishes (12 wells, $2 \times 10^{5}$ cells/well). Twenty-four hours later, the medium was replaced by serum-free Ham's F12/DMEM (1:1). On the next day, various concentrations of the following agonists were added in fresh serum-free culture medium: $\mathrm{ACTH}_{1-24}$ (Neosystem, Strasbourg, France), isoproterenol, BRL 37344 ( $\beta 3$-adrenoceptor agonist), 5-hydroxytryptamine (5-HT), Arg8-vasopressin (AVP), human chorionic gonadotropin (hCG) (all purchased from Sigma), GIP (Bachem, Voisinsle-Bretonneux, France), dobutamine (Merck, Lyon, France), salbutamol (GlaxoWellcome, Parma, Italy), desmopressin (Ferring, Gentilly, France), glucagon (Novo Nordisk,
Puteaux, France), and cisapride (kindly provided by Prof. H. Lefebvre, University Hospital of Rouen, France). After an incubation period of $2 \mathrm{~h}$, aliquots of the conditioned culture medium were taken and frozen at $-20^{\circ} \mathrm{C}$ until determination of cortisol by RIA. The elevation of cortisol in response to increased concentrations of some agonists reached a plateau, revealing the maximal effect $\left(\mathrm{E}_{\max }\right)$ of each agonist. Cultured normal adrenocortical cells were incubated with the same agonists at concentrations providing the maximal response of AIMAH cells. The effect of the non-selective $\beta$ adrenergic antagonist propranolol (Zeneca Pharma, Cergy, France) on cortisol secretion was tested in a set of experiments of AIMAH cells.

\section{Hormone assays}

Plasma and urinary cortisol and plasma aldosterone concentrations were determined by radioimmunoassay (Immunotech, Marseille, France). Cortisol concentrations in conditioned culture media were determined by radioimmunoassay (Immunotech, Marseille, France). Plasma and culture medium ACTH concentrations were measured by immunoradiometric assay (Nichols Institute Diagnostics, San Clemente, $\mathrm{CA})$, with detection limit of $0.5 \mathrm{pmol} / \mathrm{L}(2.3 \mathrm{pg} / \mathrm{mL})$.

\section{RT-PCR analysis}

After surgical resection and tumor dissection, 4 small tissue samples (around $10 \mathrm{mg}$ each) were individualized before enzymatic digestion of all tumor fragments for cell culture. These samples were collected from the diffuse hyperplastic area (figures $2 \mathrm{~A}$ and $2 \mathrm{~B}$ ) and from the two major nodules of $\mathrm{l}$ and 1.2 $\mathrm{cm}$ diameter (figures $2 \mathrm{C}$ and $2 \mathrm{D}$ ). These tissue samples were immediately frozen in liquid nitrogen and stored at $-80^{\circ} \mathrm{C}$ until RNA extraction. Thawed tissues were homogenized with the MagNA Lyser Instrument and total RNA was extracted using the High Pure RNA Tissue Kit (both from Roche Applied Science, Penzberg, Germany). The integrity of RNA was con- 

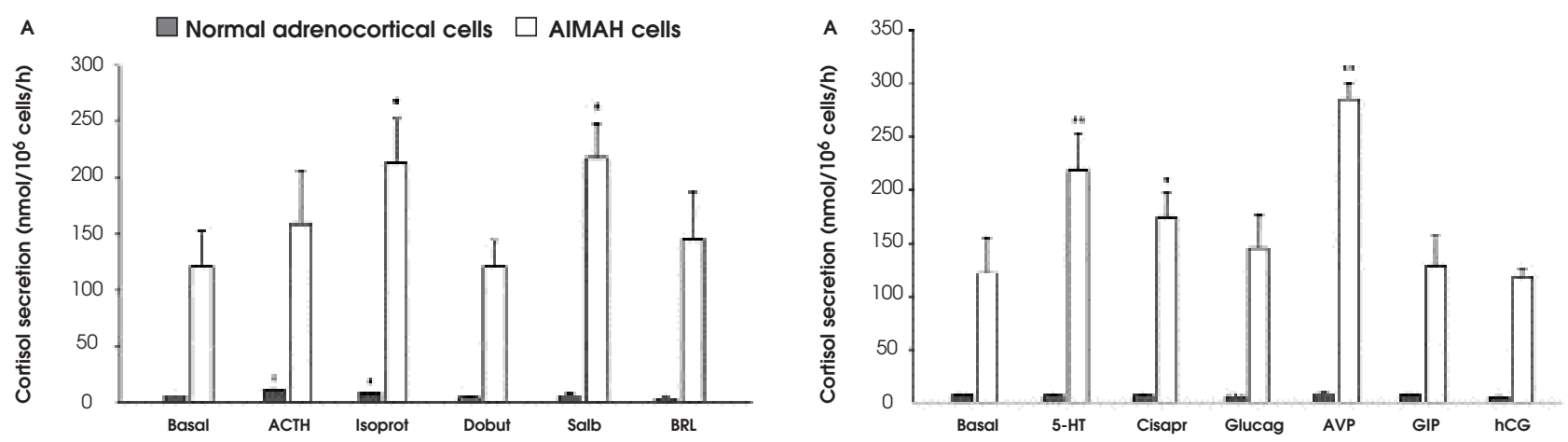

Figure 2. Maximal cortisol responses of cultured cells to stimulation by several agonists. Hyperplastic (AIMAH) and normal human adrenocortical cells were exposed for $2 \mathrm{~h}$ to different concentrations of agonists and the maximal cortisol responses $\left(E_{m a x}\right)$ were determined and shown in the figure. Histograms represent the mean + s.e.m. of cortisol concentration in conditioned medium. A) Cells were incubated with $10 \mathrm{nM} \mathrm{ACTH}$ or with the following $\beta$-adrenergic agonists: $10 \mu \mathrm{M}$ Isoprot (isoproterenol, non-selective agonist), $10 \mu \mathrm{M}$ Dobut (dobutamine, $\beta$ 1-agonist), $1 \mu \mathrm{M}$ Salb (salbutamol, $\beta 2$-agonist) or 100 nM BRL (BRL37344, $\beta 3$-agonist); B) Other agonists were tested to compare in vitro stimulation with previously described in vivo responses: 10 HM 5-HT (non-selective serotoninergic agonist), 100 nM Cisapr (cisapride, 5HT receptor agonist); 10 nM Glucag (glucagon), 10 nM AVP (vasopressin), 10 nM GIP (gastric inhibitory peptide), and 100 nM hCG (human chorionic gonadotrophin). Incubations were performed in triplicate wells in 2 or 3 different experiments $\left({ }^{*} P<0.05\right.$; ${ }^{* *} P<0.01$ vs. control).

firmed on ethidium bromide-stained agarose gels and spectophotometrically, using the $260 / 280 \mathrm{~nm}$ absorption ratio. RNA quantitation was performed by measuring the absorption at $260 \mathrm{~nm}$. Two $\mu \mathrm{g}$ of total RNA were reverse-transcribed with ImProm-II Reverse Transcriptase (Promega, Madison WI) and $0.5 \mu \mathrm{g}$ of random hexamer DNA primers, according to the conditions recommended by the manufacturer. Aliquots of 100 ng cDNA were subjected to semi-quantitative PCR in a final volume of $25 \mu \mathrm{L}$ containing 2.5 U Taq DNA polymerase (Qbiogene, Illkirch, France), and 14 pmol of each oligonucleotide primer. First, amplification of a DNA fragment of ribosomal protein L27 (RP-L27) was performed using the following pair of primers: 5'-GAACATTGATGATGGCACCTC-3' and 5'-GGGGATATCCACAGAGTACC-3'. All cDNA samples were adjusted to yield equal amplification of RP-L27 DNA fragment as internal standard and were analyzed in triplicate. The amplification parameters were $2 \mathrm{~min}$ at $94^{\circ} \mathrm{C}$, then 35 cycles each consisting of 1 min at $94^{\circ} \mathrm{C}, 1$ min at $55^{\circ} \mathrm{C}$, and $2 \mathrm{~min}$ at $72^{\circ} \mathrm{C}$. PCR reactions were also performed in nonreverse-transcripted RNA samples to exclude DNA contamination. A commercial preparation of adult human adrenal cortex RNA pooled from 11 normal glands (Human Adrenal Cortex Poly A+ RNA, Clontech, Palo Alto, CA) was used as a normal control. Amplified products were separated by agarose gel electrophoresis $(2 \%)$ and scanned using Fluorimager (Molecular Dynamics) to calculate densitometry of bands and product/RPL-27 ratios. For RT-PCR positive control, RNA from other tissues (human placenta and normal adrenal cortex adjacent to adenoma) was extracted using the same procedure. All reactions followed by electrophoresis separation were performed in triplicates.

\section{Primers design}

To amplify the single exon of the $\beta 1$-adrenoceptor (AR) gene, the primer pair 5'-TCGTGTGCACCGTGTGG
GCC-3' and 5'-AGGAAACGGCGCTCGCAGCTGTCG3' was designed, corresponding to nucleotides (nt) 638 860 of the reference sequence NM 000684 . For the single exon of the $\beta 2$-AR gene, the primer pair 5'-ACCCACCAGGAAGCCATCAACTG-3' and 5'-AACTTCCTTACGGATGAGGTTATCC-3' was designed to amplify the nt $770-1116$ fragment of the reference sequence NM 000024 . For the $\beta 3$-AR gene amplification, the primer pair 5'-GCTCCGTGGCCTCACGAGAA-3' and 5'-CCCA ACGGCCAGTGGCCAGTCAGCG-3' was designed to amplify the nt $220-490$ fragment of exon 1 according to the reference sequence NM 0000025 . For the single exon of MC2R gene, we used the primer pair 5'-GGAGTTTTGGAGAATCTGATCG-3' and 5'-ATGGTGATGTAGCGGTCCCGCAG-3' (corresponding to nt 112 - 396). Amplification of AVP receptors V1-R, V2-R, and V3-R genes was performed using previously published sequences of nucleotides (14). For 5-HT4 receptor gene, we used previously published sequence of primers that hybridize to all receptor splice variants $(15)$.

\section{Immunohistochemistry}

Deparaffinized sections of the hyperplastic tissue were incubated with the following primary antibodies: mouse monoclonal antibody against a C-terminal peptide of ACTH (1:500; Biodesign International, Saco, ME), rabbit polyclonal antibody against $\beta$-melanocyte-stimulating hormone (bMSH, 1:10000; Prof. Bachelot, Grenoble, France) and rabbit polyclonal antibody for $\beta$-endorphin (1:300; Prof Bugnon, Lyon, France). Bound antibodies were detected using the labeled streptavidin-biotin-peroxidase method (DAKO Corp., Trappes, France). Negative controls of the immunohistochemical reactions were performed by replacing the primary antibody with preimmune serum. 


\section{Statistical analysis}

Descriptive data are shown as mean \pm SEM. Variables showing normal distribution were analyzed using a two-tailed Student's t-test, whereas analyses of variance were used for variables with nonparametric distribution. $\mathrm{P}$ values less than 0.05 were considered as statistically significant, $P$ values less than 0.01 were considered as highly significant. $\mathrm{E}_{\max }$ of each agonist on cortisol secretion was expressed in percentage of basal cortisol production (without agonist). If a dose-dependent stimulation was observed, the concentration that led to $50 \%$ maximal response $\left(\mathrm{EC}_{50}\right)$ was calculated using BioDataFit 1.02 online (Chang Bioscience, Castro Valley, CA) and values were presented as a negative base 10 logarithm of the molar concentration $\left(\mathrm{pEC}_{50}\right)$.

\section{RESULTS}

\section{Clinical evaluation of cortisol responses}

Systematic search for the expression of aberrant adrenal hormone receptors according to the investigation protocol allowed to detect significant plasma cortisol response to the following stimulation tests: I) upright posture, II) terlipressin (a Vl-vasopressin receptor agonist), III) insulin-induced hypoglycemia, and IV) co-administration of glucagoncisapride (table 1). Aldosterone levels remained normal during all tests (data not shown). After a meticulous evaluation of the possible receptors involved in the orthostatism-dependent hypercortisolism, a test of cortisol secretion was performed under betablockade (propranolol, $320 \mathrm{mg} / \mathrm{d}$ ). After 3 days, the free urinary cortisol excretion was normalized (from 434 to $36 \mu \mathrm{g} / 24 \mathrm{~h}$ ). Treatment discontinuation induced reappearance of hypercortisolism, which was controlled again by the reintroduction of propranolol treatment.

\section{Cortisol response of cultured cells to hormone challenge}

After adrenalectomy and cell dispersion according previously described cell culture procedures, in vitro cortisol synthesis was evaluated. Cells from both the AIMAH catecholamine-dependent Cushing's syndrome and normal adrenal cortex (control cells) were studied. The steroidogenic effect of several receptor ligands was firstly studied by incubating cultured adrenocortical cells with increasing concentrations of agonists (data not shown). The maximal steroidogenic effect $\left(\mathrm{E}_{\max }\right)$ of each agonist is shown in figure 2 and compared to the pharmacological response of control cells to the same agonist concentration. Incubation of AIMAH cells with $10 \mathrm{nM}$ ACTH elicited a non-significant increase in cortisol levels $\left(\mathrm{E}_{\max } 132 \pm 53 \%\right)$ whereas control cells were significantly stimulated with a $\mathrm{pEC}_{50}$ of $10.1 \pm 0.2 \mathrm{M}$ (figure $2 \mathrm{~A}$ ). It should be noted, however, that the basal level of cortisol production was 30 times higher in AIMAH cells (122 $\left.\mathrm{nmol} / 10^{6} \mathrm{cells} / \mathrm{h}\right)$ than in normal cells $(4.1$ $\left.\mathrm{nmol} / 10^{6} \mathrm{cells} / \mathrm{h}\right)$. Conversely to the non-selective $\beta$ adrenoceptor agonist isoproterenol, the $\beta 2$-agonist salbutamol only induced significant cortisol stimulation in AIMAH cells $\left(\mathrm{pEC}_{50} 5.9 \pm 0.1 \mathrm{M}, \mathrm{E}_{\max } 180 \pm\right.$ $58 \%)$. Other specific agonists of $\beta$-adrenoceptors (dobutamine, $\beta 1$-agonist; BRL 37344, $\beta 3$-agonist) did not induce any significant increase in cortisol production (figure $2 \mathrm{~A}$ ).

A significant stimulation of cortisol secretion was also obtained in AIMAH cell following incubation with 5-HT and the 5- $\mathrm{HT}_{4}$ receptor agonist cisapride $\left(\mathrm{pEC}_{50} 6.1 \pm 0.2\right.$ and $7.5 \pm 0.8 \mathrm{M}$ respectively) (figure $2 \mathrm{~B})$. Moreover, AVP elicited a dose-dependent stimulation of cortisol secretion with $\mathrm{pEC}_{50} 9.6 \pm 0.1 \mathrm{M}$ in the same cells. Regarding 5-HT and AVP receptor

Table 1. Screening tests for abnormal cortisol response.

\begin{tabular}{|c|c|c|c|}
\hline \multirow[t]{2}{*}{ Screening tests } & \multicolumn{3}{|c|}{ Plasma cortisol ( $\mu \mathrm{g} / \mathrm{dL})$} \\
\hline & Basal & Peak & $\%$ of basal \\
\hline (without anti-hypertensive treatment) & 16.2 & 20.2 & 125 \\
\hline (treated by quinapril) & 20.8 & 28.4 & 137 \\
\hline Standard mixed meal & 28.4 & 19.5 & 69 \\
\hline $\mathrm{TRH}, 200 \mu \mathrm{g}+\mathrm{LHRH}, 100 \mu \mathrm{g}$ IV & 21.8 & 23.4 & 107 \\
\hline Glucagon, 1 mg IV + Cisapride, 10 mg orally & 17.9 & 22.9 & 128 \\
\hline Terlipressin, I mg IV & 24.8 & 55.9 & 225 \\
\hline Tetracosactide, $0.25 \mathrm{mg} \mathrm{IV}$ & 35.5 & 62.5 & 176 \\
\hline Desmopressin, $10 \mu \mathrm{g} \mathrm{IV}$ & 18.2 & 20.2 & 110 \\
\hline Insuline, 6U IV & 19.4 & 25.8 & 133 \\
\hline
\end{tabular}

Basal and maximum plasma cortisol values observed in response to the clinical tests (see Materials and Methods) are represented; maximum plasma cortisol variations are expressed as percentage of basal levels. A cortisol response was considered as non-significant when below $125 \%$, potentially significant when above $125 \%$, and highly significant when above $150 \%$ of basal level, as described (13). All the tests were done while patient was supine, excepting the basal cortisol at the meal and the posture test response (after $2 \mathrm{~h}$ upright). 
agonists, no significant stimulation of cortisol secretion was obtained in normal cells at the $\mathrm{E}_{\max }$ concentrations determined for AIMAH cells (figure $2 \mathrm{~B}$ ). None of the other agents (glucagon, GIP, hCG) induced any significant increase in medium cortisol levels in both cell types.

\section{Identification of $\boldsymbol{\beta 2}$-adrenoceptor mRNA in adrenal tissues}

These positive cortisol responses to various agonists in the AIMAH cells prompted us to examine the expression of their respective receptors by semi-quantitative RT-PCR. The analysis was carried out in various tissue samples: two diffuse hyperplastic areas (B and D) and
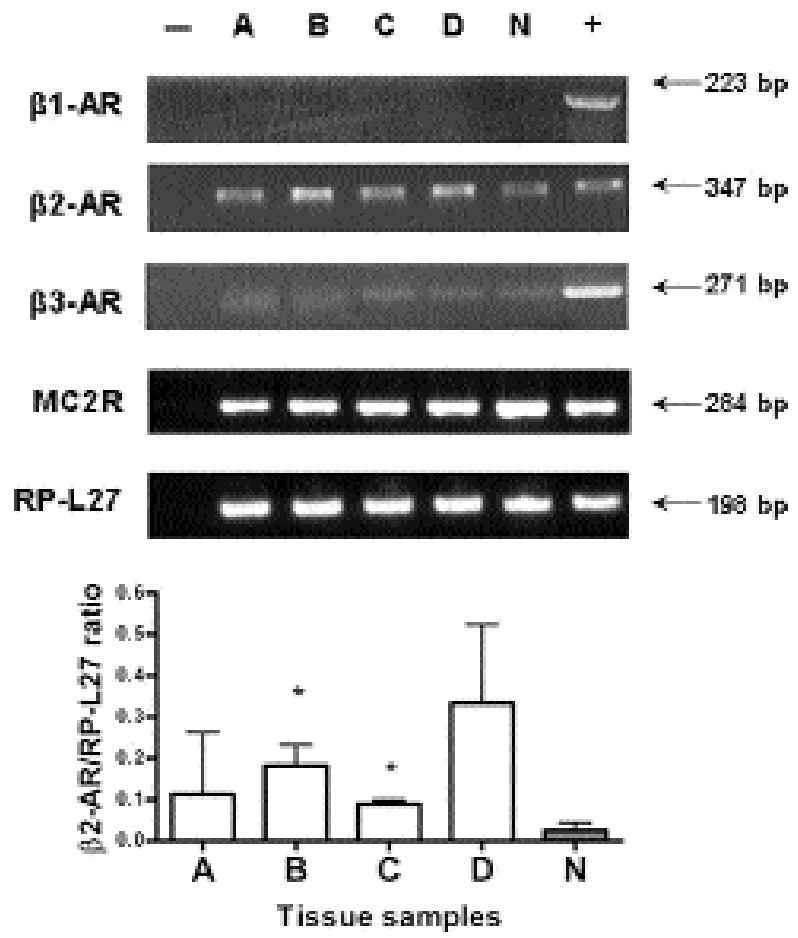

Figure 3. Expression of beta-adrenoceptors genes in human adrenal hyperplasia. $\beta 1-, \beta 2-, \beta 3-A R, M C 2 R$, and the control housekeeping RP-L27 mRNA were amplified by RT-PCR. Samples from AIMAH tissue fragments (A, B, C, and D - see figure 1) were used for separate RT-PCR reactions and compared to normal adrenal cortex mRNA (lane N, obtained from a pool of 11 human glands). Negative controls (lane-) were performed by omitting the reverse transcription step. Positive controls (lane + ) were performed using human placental RNA for $\beta$-AR and RP-L27 reactions; RNA from normal adrenal cortex adjacent to a Conn's adenoma was the positive control for MC2R reaction. The PCR products were separated by agarose gel electrophoresis, revealed by ethidium bromide and photographed under UV light. DNA markers were run in parallel to determine the sizes of amplified products shown on the right (indicated in base pairs, $\mathrm{bP})$. The quantitation of $\beta 2-\mathrm{AR}$ mRNA relative to RP-L27 mRNA signal ratio is shown in the histogram. Bars represent the mean + s.e.m. ( ${ }^{*} P<0.05$ vs. $\mathrm{N}$ (normal tissue)) . two major nodules (A and C) of AIMAH, normal adrenal cortex (a commercial preparation of RNA) and some positive control tissues as indicated in the legends of figures 3 and 4 . RT-PCR amplification of $\beta 2$ AR produced a positive signal in all AIMAH fragments, while no or very weak product amplification was obtained for $\beta 1-A R$ and $\beta 3$-AR (figure 3 ). Curiously, normal adrenal tissue also expressed the $\beta 2$-AR. The ratios of $\beta 2$-AR to RP-L27 RT-PCR signals ( mean of four fragments $=0.18$ ) indicated a slight increase in the expression level of $\beta 2$-AR in some areas of AIMAH tissues (figure 3 ) as compared to normal cortex $(\beta 2$-AR/RP-L27 ratio $=0.02)$. $\beta 2$-AR expression in normal tissue was confirmed by RT-PCR analysis with the same set of primers in several human tissues: two adrenal cortex fragments adjacent to Conn's adenomas, one adrenal cortex fragment adjacent to a cortisol-producing adenoma and another fragment adjacent to a silent adenoma (data not shown). The expression of the ACTH receptor MC2R was observed in both AIMAH tissue fragments (figure 3 ). The MC2R/RP-L27 ratio was slightly lower in AIMAH than in normal adrenal cortex or in an adrenocortical tissue fragment adjacent to a Conn's adenoma (not shown).

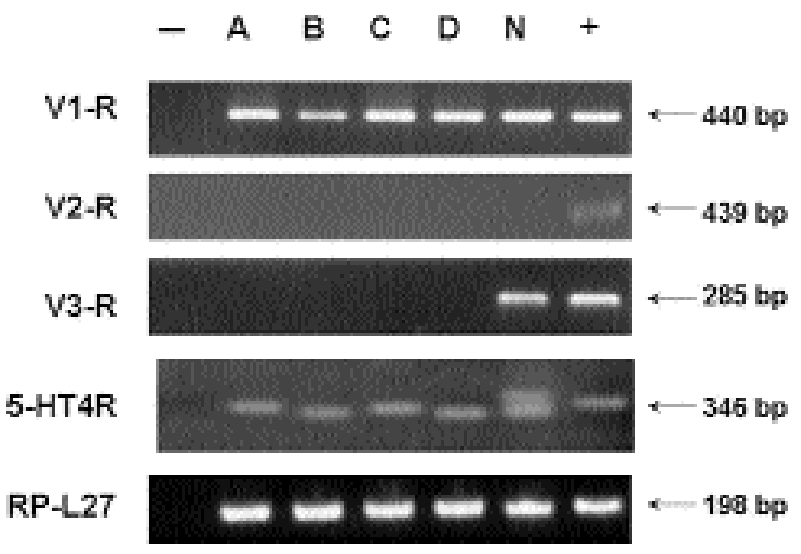

Figure 4. Amplification of vasopressin receptors and $5-\mathrm{HT}_{4}$ receptor genes. V1-R, V2-R, V3-R, 5- $\mathrm{HT}_{4} \mathrm{R}$, and the control housekeeping RP-L27 mRNA were amplified by RT-PCR. Samples from AIMAH tissue fragments (A, B, C, D) were used for separate RT-PCR reactions and compared to normal adrenal cortex mRNA (lane N, a pool of 11 human glands). Negative controls (lane -) were performed by omitting the reverse transcription step. Positive controls (lane + ) were performed using RNA from an adrenocortical tissue adjacent to a Conn's adenoma for V1-R, 5- $\mathrm{HT}_{4} \mathrm{R}$ and RP-L27 gene amplification and from human placenta for $\mathrm{V} 2-\mathrm{R}$ and V3-R gene amplification. The PCR products were separated by agarose gel electrophoresis, revealed by ethidium bromide and photographed under UV light. DNA markers were run in parallel to determine the sizes of amplified products shown on the right (indicated in base pairs, bp). 
Analysis of AVP receptor expression showed that only the adrenal receptor Vl-R was present in AIMAH tissues (figure 4). Surprisingly, a V3-R amplification product was observed in normal cortex but not in AIMAH tissue. Specific signals of different sizes were detected for 5-HT4 receptor amplification from the AIMAH and the normal adrenal cortex, which could correspond to the splice variants for this gene. It must be noted that normal mRNA was originated from a pool of 11 human adrenal glands, explaining the presence of multiple bands in the lane $\mathrm{N}$ (figure 4).

\section{Demonstration of ectopic autocrine ACTH secretion}

Although ACTH stimulation of AIMAH cells did not elicit any significant increase in cortisol production, the expression of the ACTH receptor MC2R was well demonstrated by RT-PCR in AIMAH tissue fragments. This discrepancy led us to perform several in vitro experiments in order to document more precisely the cortisol response of normal and AIMAH cultured cells challenged with ACTH. Under basal condition, a highly significant difference between basal cortisol levels of both cell types was observed (AIMAH cortisol levels were 15-fold higher than control cell cortisol levels, $P<0.001$ ) (figure 5A). This raised the possibility that a ligand for a steroidogenesis-coupled receptor might be secreted by AIMAH cells. Hypothesis of a local production of catecholamines by contaminating adrenomedullary cells or even ectopic adrenocortical synthesis of catecholamines was eliminated by the incubation of cultured medium with propranolol, a non-selective $\beta$-adrenoceptor antagonist, which did not alter cortisol secretion (figure $5 \mathrm{~A}$ ).

We then analyzed the effect of the conditioned medium from AIMAH cultured cells on cortisol production of normal cells. Addition of AIMAH conditioned medium to normal cells resulted in a strong increase (20 times) of cortisol production, after subtracting the basal concentration of cortisol in the added medium (figure 5A). The same effect was observed on primary cultures of bovine adrenocortical cells (not shown). We then assumed that ACTH could be locally produced by AIMAH cells. After $2 \mathrm{~h}$ of culture, samples of conditioned medium from normal and AIMAH cells were taken for ACTH assay. IRMA using an antiserum specifically directed against ACTH 1-39 revealed detectable ACTH levels in AIMAH medium $(1.51 \pm$ $0.26 \mathrm{pmol} / \mathrm{L}$ ), which were significantly different from the undetectable levels in control medium (figure $5 \mathrm{~B}$ ).
A

B

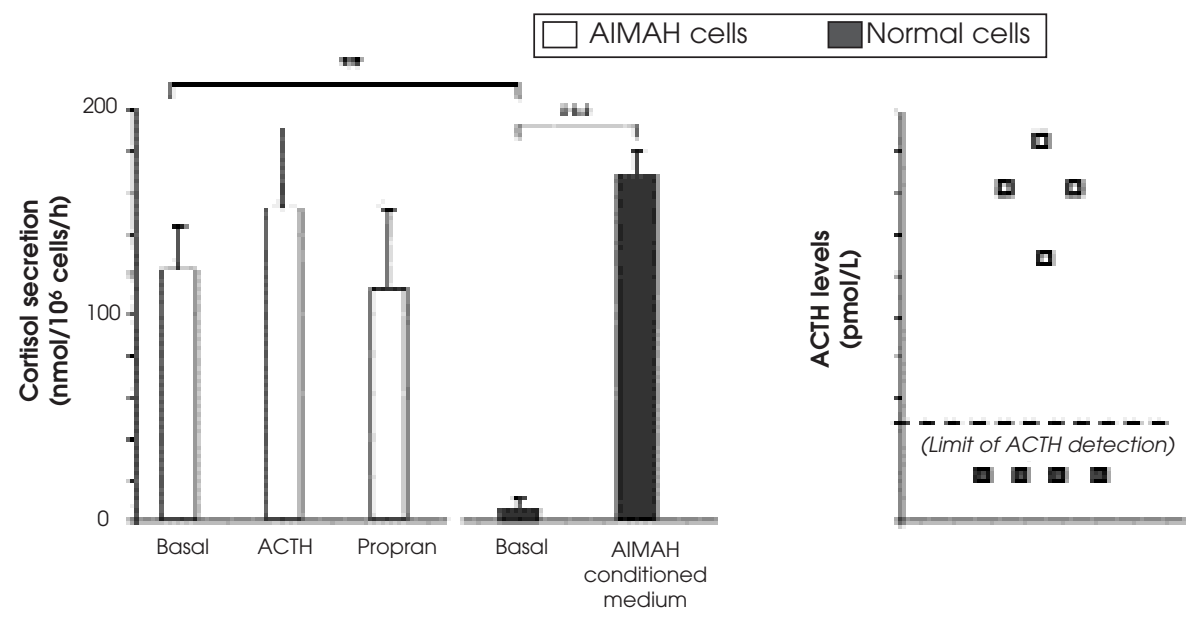

Figure 5. Cortisol production and ACTH detection in cell culture medium. A) AIMAH cells were incubated for $2 \mathrm{~h}$ in the absence (basal) or the presence of $10 \mathrm{nM}$ ACTH or $1 \mu \mathrm{M}$ of the non selective $\beta$-adrenergic antagonist propranolol (Propran). Cortisol concentrations in the conditioned media collected after $2 \mathrm{~h}$ of culture of AIMAH cells (white bars) were determined. Normal human adrenocortical cells (grey bars) were incubated for $2 \mathrm{~h}$ in the absence (basal) or the presence of AIMAH conditioned medium and cortisol secretion was then measured. For determination of the steroidogenic response of normal cells to AIMAH conditioned medium, the concentrations of cortisol initially present in the conditioned medium were subtracted from those present at the end of the incubation. Histograms represent the cortisol concentration mean + s.e.m. of quadruplicate experiments ( ${ }^{* *} P<0.01$; ${ }^{* *} P<0.001$ ). B) ACTH quantitation was performed by IRMA on conditioned media from control and AIMAH cells, collected after $2 \mathrm{~h}$ of culture $(n=4)$. Dashed lines represent the interval below detection limit $(0.5$ $\mathrm{pmol} / \mathrm{L})$. 


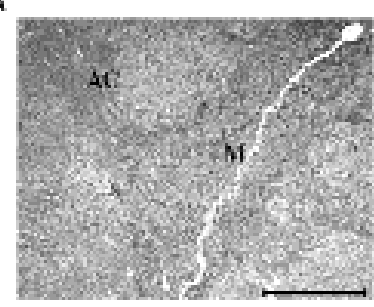

B

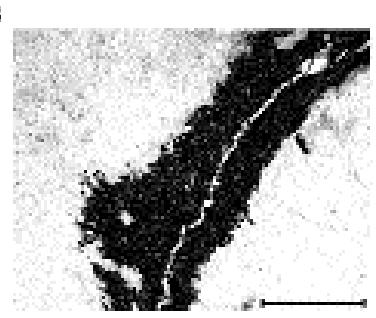

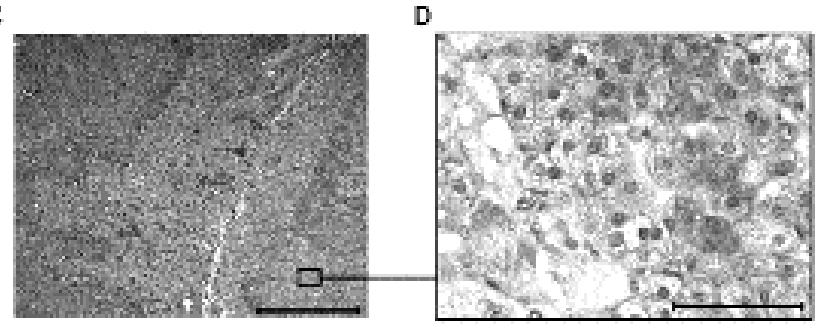

Figure 6. Immunohistological analysis of AIMAH tissue. Consecutive histological sections of AIMAH were analyzed. A) Histological staining with hematoxylin \& eosin shows adrenocortical cells (AC) distributed in homogeneous nodules and in internodular zones, in the vicinity of medullary cells (M). B) The localization of medullary cells is confirmed by immunohistochemical determination of tyrosine-hydroxylase (dark staining). C) Immunohistochemical detection of ACTH in adrenocortical AIMAH tissue. A heterogeneous staining and a diffuse distribution of positive cells are observable. Medullary cells are not stained. Bars (A, B, C), $1000 \mu \mathrm{m}$. D) Higher magnification picture of the inset shown in panel C. Bar, $200 \mu \mathrm{m}$.

This prompted us to confirm this ectopic expression of ACTH in AIMAH tissue by immunohistochemical methods. AIMAH tissue slices containing both medulla and cortex (figure 6A) were labeled with antibodies against tyrosine hydroxylase, a marker of medullary cells (figure 6B) and against the following pro-opiomelanocortin (POMC)-derived peptides: $\beta$ endorphin, $\alpha-\mathrm{MSH}$, and ACTH. Immunohistochemistry for ACTH revealed a diffuse cellular distribution in hyperplastic adrenal cortex but not in medulla (figure 6C). ACTH-positive cells had a typical aspect of spongiocytes and presented heterogeneous degrees of immunoreactivity, with some unlabelled cortical cells distributed in the tissue (figure 6D). In contrast, no immunoreactivity was observed in the adrenocortical tissue from a normal gland (data not shown). Immunohistochemical detection of $\beta$-endorphin and $\alpha-\mathrm{MSH}$ were negative in AIMAH tissues (not shown).

\section{DISCUSSION}

This study of tissue fragments and cultured cells from an autonomously secreting adrenal macronodular hyperplasia sensitive to $\beta$-blockade allowed us to identify an abnormal expression of $\beta 2$-adrenoceptors, combined with cell hyperresponsiveness to 5-HT4 and AVP, in agreement with our previous observations from the clinical investigation (4). Moreover, a local ectopic ACTH production was observed in vitro, probably contributing to the detection of basal cortisol in AIMAH cells at higher levels than in normal cells. Our results thus support the emergent notion that adrenal macronodular hyperplasia can present a mosaic of alterations, as already stated in few studies $(3,6,16)$.

Under clinical investigation, abnormal stimulation of cortisol secretion in both upright posture and insulin-induced hypoglycaemia tests suggested an aberrant expression of catecholamine receptors in this case of AIMAH. Despite a slight cortisol stimulation obtained in these tests, administration of a high dose of $\beta$-adrenergic antagonist (propranolol, $320 \mathrm{mg} / \mathrm{d}$ ) induced a strong inhibition of cortisol secretion. The identification of the precise $\beta$-AR type implicated in AIMAH catecholamine-dependent hypercortisolism may allow the use of specific beta-blocking treatment that will minimize the risk of side effects. Long-term propranolol treatment allowed the normalization of urinary cortisol levels during 9 months. Treatment with the maximum dose of atenolol (a $\beta 1$-adrenoceptor antagonist, $100 \mathrm{mg} / \mathrm{d}$ ) was less efficient than propranolol but it did significantly reduce cortisol levels (4). This observation could lead to the conclusion that $\beta 1$-adrenoceptors were implicated in AIMAH steroidogenic aberrant responses. Nevertheless, in the current work, we demonstrate in vitro cortisol responses to both a non-selective adrenoceptor agonist (isoproterenol) and a $\beta 2$ - selective (salbutamol) agonist in AIMAH cultured cells, but no response to $\beta 1$ or $\beta 3$-adrenoceptor agonists. These data are in agreement with the results of RT-PCR analysis which revealed mRNA expression of $\beta 2$-AR but not $\beta 1$-AR in all the AIMAH fragments studied. Even though a clinical treatment with $\beta 1$-AR antagonist had some inhibitory effect on the systemic cortisol secretion, the present in vitro studies rule out its involvement as an ectopic receptor and establish the role of $\beta 2-\mathrm{AR}$ inducing the hypercortisolism. Such clinical demonstration of cortisol levels reduction after high doses of the $\beta 1$-AR antagonist atenolol might be explained by the loss of selectivity of beta-blockers, which is often observed at maximal therapeutic doses $(17,18)$.

A novel aspect of aberrant $\beta$-AR expression is raised by the detection of $\beta 2$-AR mRNA in normal adrenal cortex. This result was confirmed by performing successful RT-PCR amplification of this gene 
using mRNA samples from 4 specimens of normal human adrenal cortex. It leads to conclude that $\beta 2$-AR was overexpressed rather than ectopically $(1,11)$ expressed in the studied AIMAH tissue. Most works reporting $\beta$-AR expression in adrenocortical tissues used functional assays (9) and indicated no response of normal human adrenocortical cells to catecholamine stimulation. Besides the human species, cultured bovine adrenocortical cells show steroidogenic stimulation through the $\beta$-adrenergic receptors according to our unpublished results and to other authors (19). Concerning molecular studies, the presence of $\beta 2$-AR mRNA in human adrenal gland was demonstrated by one group (20). However, the RNA from total adrenal gland used in these experiments could have been contaminated by medullary tissue, which expresses $\beta$ ARs (21). Furthermore, $\beta 1-, \beta 2-$, and $\beta 3$-AR mRNA were detected in human adrenal tumor-derived cells (22). If $\beta 2-A R$ is present in normal adrenal cortex, it does not seem to be coupled to steroidogenesis, as we observed in in vitro steroidogenic response to salbutamol at pharmacological concentrations. Only isoproterenol elicited an unexpected cortisol response in normal cells. Finally, this subject is quite controversial and requires extensive functional and molecular explorations to decipher the biological role of $\beta 2$-adrenoceptor in normal adrenal cortex.

In addition to the upright posture and insulininduced hypoglycaemia tests performed in this study, systematic in vivo search for the expression of aberrant adrenal hormone receptors has been successful with other pharmacological agents: terlipressin (a Vl-vasopressin receptor agonist) and combined glucagon-cisapride administration (4). Further clinical explorations led to consider these responses as minor in comparison to the $\beta$-adrenergic response. In fact, in normal subjects, these tests do not increase plasma cortisol levels. The incubation of cultured AIMAH cells with 5-HT, cisapride, and AVP resulted in significant cortisol stimulation, but treatment with glucagon did not. As analyzed by RT-PCR, expression of AVP receptors and $5-\mathrm{HT}_{4} \mathrm{R}$ were not increased in AIMAH tissues. As expected, $\mathrm{VI}-\mathrm{R}$ and $5-\mathrm{HT}_{4} \mathrm{R}$ were expressed in normal adrenal cortex. Overexpression of the mRNAs encoding the eutopic $\mathrm{Vla}$ and $5-\mathrm{HT}_{4}$ receptors has been described in tissue explants removed from AIMAHs responsive to AVP and cisapride in vivo, respectively (23-26). Conversely, the present AIMAH tissue presented serotonin and vasopressin hyperresponsivenes unrelated to the degree of mRNA Vl-R and $5-\mathrm{HT}_{4} \mathrm{R}$ expression, which could be explained by differences in receptor sensitivity or in corticosteroidogenesis cou- pling. In particular, the $5-\mathrm{HT}_{4} \mathrm{R}$ gene is normally expressed in adrenal cortex while the receptor stimulation by serotonin triggers aldosterone secretion (27). Variants of this receptor may exhibit different coupling efficiencies (28). According to the present AIMAH, few patients with 5 - $\mathrm{HT}_{4}$-dependent AIMAH have presented levels of mRNA expression similar to normal glands (25). In addition, in a study of vasopressinresponsive adrenocortical tumors, it was demonstrated that only a minority of tissues expressed large amounts of the Vl-R (29).

In the last decade, several $G$ protein-coupled receptors have been shown to be involved in adrenal hypercortisolism, including receptors for cathecolamines, GIP, AVP, LH/hCG, and serotonin (1). However, it was unclear if the aberrant GPCR expression was the cause or the consequence of the adrenal mass development. Recently, we have demonstrated that the enforced gene expression of the non-mutated GIP receptor (30) or LH/hCG receptor (31) can initiate phenotypic alterations in adrenal cortex. In the present work, whether the overexpression of $\beta 2$ adrenoceptor in adrenal hyperplasia is sufficient to cause both hypercortisolism and tumorigenesis is still an open question. The experimental model of xenotransplantation using genetically modified adrenocortical cells (32) could contribute to better understand the pathogenetic role of $\beta 2$-adrenoceptors. Moreover, another intriguing point of research in this field is the molecular mechanism responsible for the aberrant expression of $\mathrm{G}$ protein-coupled receptors. In this regard, the GIP receptor gene is the most studied, including molecular analysis of its gene promoter (33) and specific transcription factors (34). Such studies and more recently the identification of several target candidate genes (35) are contributing to clarify the causative alterations leading to aberrant expression of hormonal receptors in adrenal cortex.

According to our results, cortisol secretion of cultured AIMAH cells did not significantly increase in response to ACTH stimulation, although the MC2R was expressed in all AIMAH tissue fragments. Similarly to in vitro stimulation, in vivo administration of synthetic $\mathrm{ACTH}_{1-24}$ resulted in a rather moderate cortisol response (4) as compared to the strong plasma cortisol increase (about 300-600\%) published in several cases of AIMAH (2,3,36-38). In fact, AIMAH cells in culture produced very elevated cortisol levels even under basal conditions. We tested the effect of propranolol on AIMAH cells and observed no modification on basal cortisol secretion, excluding an eventual autocrine $\beta$-adrenergic stimulation loop. Increased cortisol 
levels observed in normal cells incubated with AIMAH conditioned medium supplied further evidence that an autocrine factor/s produced by AIMAH cells was/were secreted in the culture medium and could stimulate normal cells even without any aberrant receptor expression. As no ACTH antagonist is currently available, we tried to detect ACTH in culture medium by specific IRMA. We could measure ACTH concentrations about $1.5 \mathrm{pmol} / \mathrm{L}$. Such concentration is sufficient to exert pharmacological stimulation on MC2R. Accordingly, a recent study showed intraadrenal ACTH production of about $3-5 \mathrm{pmol} / \mathrm{L}$ in perifused adrenocortical explants (39). As ACTH plasma levels of these Cushing's patients were also suppressed, we can conclude that the amount of local ACTH production is insufficient to be detected in the blood.

ACTH is derived by cleavage from its precursor, POMC. In order to authenticate ACTH adrenal production, we performed immunohistochemistry (IHC) analysis to detect POMC-derived peptides. It had been demonstrated that ACTH can be synthesized and released by adrenochromaffin cells $(40,41)$, so we first identified the distribution of medullary cells within the hyperplasic adrenal mass. ACTH immunodetection in adrenocortical hyperplasia is quite common when adrenochromaffin cells are ectopically dispersed in the middle of the adrenocortical mass, being able to produce ACTH (42). According to our results, ACTH immunoreactivity of AIMAH cells was unrelated to the histological localization of medullary cells (figure 6). Taken together, IRMA and IHC detections of ACTH confirm the hypothesis of a local factor able to stimulate normal adrenocortical cells, demonstrating an ectopic autocrine ACTH production by AIMAH cells. It agrees with recent evidence indicating a local production of ACTH, AVP or 5-HT in adrenocortical cortisol-producing hyperplasias that can act as ectopic ligands $(16,39)$. This autocrine mechanism should contribute to maintain a basal adrenal cortisol production.

Finally, the present in vitro study of adrenal cortisol autonomy due to a bilateral hyperplasia demonstrates that the so-called ACTH-independent macronodular adrenal hyperplasia (AIMAH) can actually present an atypical form of ACTH-dependency by local ectopic production. Moreover, we demonstrate that abnormal clinical responsiveness to catecholamines is a result of abnormal expression of $\beta 2$-adrenoceptors in this case of adrenal hyperplasia, which also shows $5-\mathrm{HT}_{4}$ and AVP hyperresponsiveness. This association of mediators of adrenal response supports the recent observations that AIMAH may simultane- ously express multiple illegitimate membrane receptors and/or present paracrine/autocrine regulatory signals.

\section{ACKNOWLEDGEMENTS}

We thank the physicians S. Favre, who referred the patient, and C. Vadot, who conducted her follow-up, and C. Guillermet for her assistance in immunostaining. T.L.M. was supported by a doctoral studentship from Agency for the Improvement of Graduate Training of Brazil (CAPES).

\section{REFERENCES}

1. Lacroix A, Baldacchino V, Bourdeau I, Hamet P, Tremblay J. Cushing's syndrome variants secondary to aberrant hormone receptors. Trends Endocrinol Metab 2004;15:375-82.

2. Lacroix A, Tremblay J, Rousseau G, Bouvier M, Hamet P. Propranolol therapy for ectopic beta-adrenergic receptors in adrenal Cushing's syndrome. N Engl J Med 1997;337:142934.

3. Mircescu H, Jilwan J, N'Diaye N, Bourdeau I, Tremblay J, Hamet $P$, et al. Are ectopic or abnormal membrane hormone receptors frequently present in adrenal Cushing's syndrome? J Clin Endocrinol Metab 2000;85:3531-6.

4. Mazzuco TL, Martinie M, Favre S, Bachelot I, Chabre O. ACTHindependent Cushing's syndrome treated solely with propranolol therapy. The Endocrine Society's 84th Meeting; 2002. San Francisco, CA.

5. Imohl M, Koditz R, Stachon A, Muller KM, Nicolas V, Pfeilschifter J, et al. [Catecholamine-dependent hereditary Cushing's syndrome - follow-up after unilateral adrenalectomy]. Med Klin (Munich) 2002;97:747-53.

6. Miyamura N, Tsutsumi A, Senokuchi H, Nakamaru K, Kawashima J, Sakai K, et al. A case of ACTH-independent macronodular adrenal hyperplasia: simultaneous expression of several aberrant hormone receptors in the adrenal gland. Endocr J 2003;50:333-40.

7. Pignatelli D, Rodrigues E, Barbosa AP, Medina JL. Cushing syndrome due to the ectopic expression of adrenergic receptors in the adrenal cortex. A Case of ACTH Independent Macronodular Adrenal Hyperplasia (AIMAH). The Endocrine Society's 86th Meeting; 2004. New Orleans, LA.

8. Schorr I, Rathnam P, Saxena BB, Ney RL. Multiple specific hormone receptors in the adenylate cyclase of an adrenocortical carcinoma. J Biol Chem 1971;246:5806-11.

9. Williams LT, Gore TB, Lefkowitz RJ. Ectopic beta-adrenergic receptor binding sites. Possible molecular basis of aberrant catecholamine responsiveness of an adrenocortical tumor adenylate cyclase. J Clin Invest 1977;59:319-24.

10. Matsukura S, Kakita T, Sueoka S, Yoshimi H, Hirata Y, Yokota $\mathrm{M}$, et al. Multiple hormone receptors in the adenylate cyclase of human adrenocortical tumors. Cancer Res 1980;40:3768-71.

11. Katz MS, Kelly TM, Dax EM, Pineyro MA, Partilla JS, Gregerman RI. Ectopic beta-adrenergic receptors coupled to adenylate cyclase in human adrenocortical carcinomas. $J$ Clin Endocrinol Metab 1985;60:900-9.

12. Hirata Y, Uchihashi M, Sueoka S, Matsukura S, Fujita T. Presence of ectopic beta-adrenergic receptors on human adrenocortical cortisol-producing adenomas. J Clin Endocrinol Metab 1981;53:953-7.

13. Lacroix A, Hamet P, Boutin JM. Clinical evaluation of the presence of abnormal hormone receptors in adrenal Cushing's syndrome. Endocrinologist 1999;9:9-15. 
14. Perraudin V, Delarue C, De Keyzer Y, Bertagna X, Kuhn JM Contesse V, et al. Vasopressin-responsive adrenocortical tumor in a mild Cushing's syndrome: in vivo and in vitro studies. J Clin Endocrinol Metab 1995;80:2661-7.

15. Lefebvre H, Cartier D, Duparc C, Lihrmann I, Contesse V, Delarue $C$, et al. Characterization of serotonin(4) receptors in adrenocortical aldosterone-producing adenomas: in vivo and in vitro studies. J Clin Endocrinol Metab 2002;87:1211-6.

16. Bertherat J, Contesse V, Louiset E, Barrande G, Duparc C, Groussin L, et al. In vivo and in vitro screening for illegitimate receptors in adrenocorticotropin-independent macronodular adrenal hyperplasia causing Cushing's syndrome: identification of two cases of gonadotropin/gastric inhibitory polypeptide-dependent hypercortisolism. J Clin Endocrinol Metab 2005;90:1302-10.

17. Smith C, Teitler M. Beta-blocker selectivity at cloned human beta 1 - and beta 2-adrenergic receptors. Cardiovasc Drugs Ther 1999;13:123-6.

18. Wood AJ. Pharmacologic differences between beta blockers. Am Heart J 1984;108:1070-7.

19. Kawamura M, Nakamichi N, Imagawa N, Tanaka Y, Tomita C, Matsuba M. Effect of adrenaline on steroidogenesis in primary cultured bovine adrenocortical cells. Jpn J Pharmacol 1984;36:35-41.

20. Thomas RF, Liggett SB. Lack of beta 3-adrenergic receptor mRNA expression in adipose and other metabolic tissues in the adult human. Mol Pharmacol 1993;43:343-8.

21. Boksa P. Studies on the uptake and release of propranolol and the effects of propranolol on catecholamines in cultures of bovine adrenal chromaffin cells. Biochem Pharmacol 1986;35:805-15.

22. Kosti O, King PJ, Hinson JP. Tumour-derived human adrenocortical cells express beta-adrenergic receptors: steroidogenic effects of beta-adrenergic input. Endocr Res 2002;28:363-7.

23. Tatsuno I, Uchida D, Tanaka T, Koide H, Shigeta A, Ichikawa T, et al. Vasopressin responsiveness of subclinical Cushing's syndrome due to ACTH-independent macronodular adrenocortical hyperplasia. Clin Endocrinol (Oxf) 2004;60:192-200.

24. Mannelli M, Ferruzzi P, Luciani P, Crescioli C, Buci L, Corona $\mathrm{G}$, et al. Cushing's syndrome in a patient with bilateral macronodular adrenal hyperplasia responding to cisapride: an in vivo and in vitro study. J Clin Endocrinol Metab 2003;88:4616-22.

25. Cartier D, Lihrmann I, Parmentier F, Bastard C, Bertherat J, Caron $\mathrm{P}$, et al. Overexpression of serotonin4 receptors in cisapride-responsive adrenocorticotropin-independent bilateral macronodular adrenal hyperplasia causing Cushing's syndrome. J Clin Endocrinol Metab 2003;88:248-54.

26. Mune T, Murase H, Yamakita N, Fukuda T, Murayama M, Miura A, et al. Eutopic overexpression of vasopressin v1a receptor in adrenocorticotropin-independent macronodular adrenal hyperplasia. J Clin Endocrinol Metab 2002; 87:5706-13.

27. Lefebvre $\mathrm{H}$, Contesse V, Delarue C, Soubrane C, Legrand A, Kuhn JM, et al. Effect of the serotonin-4 receptor agonist zacopride on aldosterone secretion from the human adrenal cortex: in vivo and in vitro studies. $J$ Clin Endocrinol Metab 1993;77:1662-6.

28. Pindon A, van Hecke G, van Gompel P, Lesage AS, Leysen JE, Jurzak M. Differences in signal transduction of two 5-HT4 receptor splice variants: compound specificity and dual coupling with Galphas- and Galphai/o-proteins. Mol Pharmacol 2002;61:85-96.

29. Arnaldi G, Gasc JM, de Keyzer Y, Raffin-Sanson ML, Perraudin V, Kuhn JM, et al. Variable expression of the V1 vasopressin receptor modulates the phenotypic response of steroid-secreting adrenocortical tumors. J Clin Endocrinol Metab 1998;83:2029-35.

30. Mazzuco TL, Chabre O, Sturm N, Feige JJ, Thomas M. Ectopic expression of the gastric inhibitory polypeptide receptor gene is a sufficient genetic event to induce benign adrenocortical tumor in a xenotransplantation model. Endocrinology 2006;147:782-90.
31. Mazzuco TL, Chabre O, Feige JJ, Thomas M. Aberrant expression of human luteinizing hormone receptor by adrenocortical cells is sufficient to provoke both hyperplasia and Cushing's syndrome features. J Clin Endocrinol Metab 2006;91:196-203.

32. Mazzuco TL, Chabre O, Feige JJ, Thomas M. Aberrant GPCR expression is a sufficient genetic event to trigger adrenocortical tumorigenesis. Mol Cell Endocrinol 2007;265-266:238.

33. Antonini SR, N'Diaye N, Baldacchino V, Hamet P, Tremblay J, Lacroix $A$. Analysis of the putative regulatory region of the gastric inhibitory polypeptide receptor gene in food-dependent Cushing's syndrome. J Steroid Biochem Mol Biol 2004; $91: 171-7$.

34. Baldacchino V, Oble S, Decarie PO, Bourdeau I, Hamet $P$, Tremblay J, et al. The Sp transcription factors are involved in the cellular expression of the human glucose-dependent insulinotropic polypeptide receptor gene and overexpressed in adrenals of patients with Cushing's syndrome. $J$ Mol Endocrinol 2005;35:61-71.

35. Lampron A, Bourdeau I, Hamet P, Tremblay J, Lacroix A. Whole genome expression profiling of glucose-dependent insulinotropic peptide (GIP)- and adrenocorticotropin-dependent adrenal hyperplasias reveals novel targets for the study of GIP-dependent Cushing's syndrome. J Clin Endocrinol Metab 2006;91:3611-8.

36. Daidoh H, Morita H, Hanafusa J, Mune T, Murase H, Sato M, et al. In vivo and in vitro effects of AVP and $\mathrm{V} 1 \mathrm{a}$ receptor antagonist on Cushing's syndrome due to ACTH-independent bilateral macronodular adrenocortical hyperplasia. Clin Endocrinol (Oxf) 1998;49:403-9.

37. Mircescu H, Jilwan J, N'Diaye N, Bourdeau I, Tremblay J, Hamet $\mathrm{P}$, et al. Are ectopic or abnormal membrane hormone receptors frequently present in adrenal Cushing's syndrome? J Clin Endocrinol Metab 2000;85:3531-6.

38. Lacroix A, Tremblay J, Rousseau G, Bouvier M, Hamet P. Propranolol therapy for ectopic beta-adrenergic receptors in adrenal Cushing's syndrome. N Engl J Med 1997;337:142934.

39. Lefebvre H, Duparc C, Chartrel N, Jegou S, Pellerin A, Laquerriere $A$, et al. Intraadrenal adrenocorticotropin production in a case of bilateral macronodular adrenal hyperplasia causing Cushing's syndrome. J Clin Endocrinol Metab 2003; 88:3035-42.

40. Willenberg HS, Bornstein SR, Hiroi N, Path G, Goretzki PE, Scherbaum WA, et al. Effects of a novel corticotropin-releasing-hormone receptor type I antagonist on human adrenal function. Mol Psychiatry 2000;5:137-41.

41. Suda T, Tomori N, Tozawa F, Demura H, Shizume K, Mouri T, et al. Immunoreactive corticotropin and corticotropin-releasing factor in human hypothalamus, adrenal, lung cancer, and pheochromocytoma. J Clin Endocrinol Metab 1984; 58:919-24.

42. Pereira MA, Araújo RS, Bisi H. Síndrome de Cushing associada à hiperplasia macronodular das adrenais: apresentação de um caso e revisão da literatura. Arq Bras Endocrinol Metab 2001;45:619-27.

\section{Address for correspondence}

Tânia Longo Mazzuco

Depto. Ciências Patológicas - CCB

Universidade Estadual de Londrina

Rodovia Celso Garcia Cid, Pr 445, Km 380

Caixa Postal 6001

86051-990 Londrina, PR

Fax: (43) 3371-4465

E-mail: tmazzuco@uel.br / tmazzuco@gmail.com 